\title{
Human Resource Accounting System in Selected Indian Companies
}

\author{
Upasna Joshi ${ }^{1},{ }^{*}$ Reeta Mahei ${ }^{2}$ \\ 1Punjab School of Management Studies, Mohali, India \\ 2Zakir Husain Delhi College, University of Delhi, India \\ *inforeeta@yahoo.com
}

\begin{abstract}
The human resource may be seen as the most fundamental of all available resources to an economy or an organization. Human resources are energies, skills, talents and knowledge of people that are or can be potentially applied to the production of goods and services. Corporations cannot run by machines or systems alone, however smart those may be. The human element in it is inevitable, even for knowledge based lean organizations of the $21^{\text {st }}$ century. It is an irony that valuation of this important asset is not reflected in the books of accounts. However to enhance goodwill and attract investors, need is being felt for human resource accounting. In our present paper, an attempt has been made to do the comparative study of the human resource accounting practices of CCI, HPCL, Infosys and Rolta India Limited. The variables that are important for the purpose of human resource accounting are identified and by analyzing, the annual reports of these selected companies scores are assigned to the organizations and mean scores for these organizations were calculated. Ranks to the organizations are also given based upon the extent of the HRA information reported in their annual reports.
\end{abstract}

Key words: Human Resource Accounting, Human Resources, Lev and Schwartz Model, Present Value of Future Earnings, Human Capital accounting

\section{Introduction}

Human Resource factor is very crucial, important and sensitive factor of production. It is a widely accepted fact that success of any organization, to a great extent, depends upon the quality, caliber and character of the people working in it. An organization having immense physical resources with latest technology may suffer financial crises as it does not have right people to manage and to conduct its affairs. Thus, to in spite of technological developments, the importance of human resources to ensure the organization's success has no way abridged. Yet accounting has concentrated on the physical and financial resources of an entity, without bringing this vital ingredient of social system into its fold forgetting that the performance of the enterprise itself is the product of human activity and the failure of most of the organizations is due to the poor performance of its people. Realizing the importance of human resources, the accountants and economists all over the world became conscious and this has led to the development and implementation of Human Resource Accounting along with financial statements.

American Accounting Association (1973) defines Human Resource Accounting: as "the process of identifying and measuring data about human resources and communicating this information to the interested parties." Human Resource Accounting emphasizes that human resources should be treated as assets like physical and financial assets because the quality and caliber of the people working in an organization are the real assets for a firm. HRA is mainly concerned with:

- Identification of data regarding human resources of an organization.

- Measurement of the data in terms of cost and value.

- Communicating this information to the interested parties.

Human Resource Accounting is of high significance not only for the management but also for the analyst and the employees. It helps the management in better planning, utilization and management of human resources of the organization. For the analyst it provides information regarding the inner strength of the organization and also helps in making decisions regarding the long term investment in that organization. This also affects bargaining power and performance of employees. Despite this importance of HRA, the study of human 
resources of an organization has not received the attention it deserves. It is unfortunate that though a lot of work has been done in this field there is no method that is generally accepted either for valuation of human resources nor for the disclosure information by means of different statements. Despite these problems, there are some organizations that are making valuation of their human resources. However, in this context we face the problem in making a fair comparative study of the human resources of two organizations, as they do not follow the same approach of valuation of human resources. Many companies, in the absence of any compulsion fail to disclose the details regarding the human resources in their financial statements. Despite all the progress made in this area, much is yet to be done. The organizations need to be aware of and sensitive to the importance of human resources. In the present paper, an effort has been made to touch some aspects of human resource accounting. A comparative study of selected companies has been undertaken to find out that how the companies disclose HRA information in their annual reports. Certain important variables concerned with the valuation of human resources have been identified in order to see whether these selected organizations are reporting these variables or not as the reporting of these affect the decision of interested parties. They further affect the decision when a comparative study is done involving different organizations.

\section{Review of Literature}

The concept of human capital is not a recent discovery. Its origin dates back to the late seventeenth century when the economists, Sir William Petty first attempted to estimate the monetary value of population of England in 1681. He considered labor as the father of wealth and stressed that it should be included in the estimate of the total national wealth. The credit for recognizing the value of human resources as an asset goes to Paton (1962). When he commented, "in a business a well organized and loyal personnel may be a more important asset than a stock of merchandise." The fact remains; however, that it was Likert (1967). Social Psychologist, The institute for Social Research, University of Michigan, who first use the term 'human asset' a term since replaced by human resources. Therefore, he originally developed it. Different techniques have been developed to measure the value of human resources. The original cost model of Brummet et al. (1968) suggested to capitalize the firm's expenditure on recruitment, selection, training and development of human resources, amortizing such costs over a period and hence reporting the net investment in human resources in the Balance Sheet under the heading human assets. R.G Barry corporation of U.S.A during 1968-74 implemented this method for valuation of human resources and reported this information externally. Replacement cost approach was developed by Likert and Flamholtz in 1973. The cost of alternative use of employee is value of human resources as per this approach. Hekimian and Jones (1967) gives an Opportunity Cost Approach based on the principle that human assets will be valued while it is scarce. Hermanson (1964) proposed an adjusted present value model to quantify the value of human capital of a company. He suggested that the amount of future wages payable represents a liability while human resources as an asset in the Balance Sheet. Lev and Schwartz (1971) valued human capital as the present value of future earnings of employee till retirement. Flamholtz (1971) developed Stochastic Rewards Valuation model and determined the value of human assets by aggregating the present value of expected future services of employees. Jaggi and Lau (1974) model considers groups for valuation rather than individuals. As per Giles and Robinsons (1972) Human Asset Multiplier Model the capitalized value of the company calculated on the basis of price earnings ratio minus net assets are the human resources.

Morse (1973) in his net benefit method considers that human resources value is equal to the present value of the gross value of services to be rendered by human beings minus present value of the future payments to human beings. Ogan's (1976) suggested a model known as "Certainty Equivalent Net Benefit Model" that is the extension of net benefit model of Morse. Certainty with which the net benefit in future will accrue to the organization is the value of human resources. Chakraborty (1976) suggested a model for valuation of human resources known as Aggregate Payment Approach. The value of human resources is calculated by multiplying the average salary with the average tenure of the employee. Dasgupta (1978) also gives his total cost concept to value the human resources. Likert (1967), Flamholtz (1972), Myer's and flowers (1974), suggested the non-monetary approaches for assessing the economic value of human resources that measures the human resources not in dollar or money terms rather they rely on various indices or ratings and rankings. Different studies have been conducted time to time. Elias (1972) conducted the first published research concerning the effect of human 
resource outlay data on stock investment decisions. For this, he selected two hypothetical companies ABC and $\mathrm{XYZ}$ operating in the same industry. Two different sets of financial statements were prepared and supplied to the Chartered Financial Analysts, certified Public Accountants and accounting students asking them to choose the company for their investment based on the analysis of the given financial statements. The choice decision of the respondents varied when the HRA information along with the traditional information was supplied. This shows the importance of providing HRA data in addition to conventional data. Gambling (1974) suggested a system dynamics approach to human resource accounting considering an organization as a dynamic system with feedbacks. Flamholtz (1976) carried out an experimental study of the impact of human resource valuation on managerial decision-making. He found significant differences in decisions taken by those who used traditional trait evaluations relative to those who used two types of HRA data. Schwan (1976) studied the effects of human resource cost measures on banker making decision-making.

For the purpose of his study, the participants were managers and analysts employed in investment, credit and trust departments of large banks. Schwan found that the inclusion of HRA data in published statements resulted in significantly different ratings of management's preparedness to meet the future challenges and opportunities and statistically different predictions of a firms 'net income'. Tomassini (1977) in his study concluded that HRA cost estimates caused different managerial preferences in the personnel lay off decision context. Gul (1984) attempted to study the usefulness of human resources turnover cost information for the labor turnover decision making in a sample of Australian Accounting firms. The results of the study concluded that human resource turnover cost information significantly reduced accountant's level of uncertainty and increased their level of relevance and sufficiency. All these studies showed the relevance of HRA information in various decisions. Gupta (1990), Bhatia and Singh, (1992), Rao (1993), Batra and Bhatia (1994), Prakash (1997), Verma (1999), Patra and Khalik (2003), Sonara and Patel (2009) conducted a study to know the current status of human resource accounting in Indian Context. All these studies were conducted to find out the current practices followed by the Indian organizations for HRA. The studies concluded that very few companies come forward for reporting HRA as it is not compulsory for them to disclose human resources information in their annual reports. The present paper is an attempt to critically review the HRA practices of selected organization with a step forward to rank the organizations based on their extent of disclosure of HRA information. An attempt also been made to rank the items that companies disclosed more and the relevance of such disclosure.

The main objectives of the present study are:

- To investigate the practices of the selected Indian companies in valuing their human resource.

- To make a critical analysis of the human resource accounting practices followed by the selected companies.

- To rank the organizations based on extent of disclosure of human resource accounting information in their annual reports.

\section{Methodology}

The purpose of the present research is to do the comparative study of the selected organizations in India to find the status of HRA reporting practices of Indian companies. In the present study, the purposive sampling technique has been used for the selection of the companies. Two companies from public sector and two from private sector are selected for the purpose of study. The selection of the above organizations is influenced by their favorable response and representative nature of the selected companies in respective industries as well as the Indian economy. These companies are presently valuing their human resources and showing their value in their annual reports. Most of the secondary data needed is collected from the published annual reports of the selected companies. The annual reports of the selected companies were scanned for the period ranging from 2006-07 to 2010-11 to find out the HRA system of these organizations. To rank the organizations on the basis of the information disclosed by these companies in their annual reports certain variables were identified and scores for each variable are assigned and on the basis of mean scores ranks were provided to selected organizations. Disclosure of these variables related to the human resources will help the interested parties to take various decisions. A comparative study of the organizations human resources will be based on these variables.

The following companies are selected for the purpose of this study. 
- Cement Corporation of India (CCI)

- Hindustan Petroleum Corporation Limited (HPCL)

- Infosys Technologies Limited.

- Rolta India Limited.

\section{Results and Discussion}

Human Resource Accounting System of Cement Corporation of India: Cement Corporation of India Limited was incorporated as a company wholly owned by Government of India on $18^{\text {th }}$ Jan 1965 . It was established with the objective to achieve a pioneering and leading position in the exploration of cement grade limestone reserves and to emerge as a dominant leader in the production of cement in the country.CCI branded human resources as 'Mother Resources' through which other scarce resources viz., machines, material, money are organized, coordinated, directed and controlled.CCI made an attempt to value its human resources by working out the present value of anticipated future earnings taking into account the present pay scales and promotion policies being followed. The computation has been based on the guidelines and principles enunciated in the economic models developed by Lev \& Schwartz, Eric Flamholtz and Jaggi and Lau with appropriate modifications.

Human Resource Accounting System of HPCL: Hindustan Petroleum Corporation Limited, a Fortune 500 company, is one of the major integrated oil refining and marketing company in India. It is a Mega Public Sector Undertaking (PSU) with navratna status. HPCL uses Lev \& Schwartz model for the purpose of computation of value of human resources. The company considers all direct and indirect benefits given to employees as a basis for valuation of human resources.

Human Resource Accounting System of Infosys: Infosys is a leading information technology company that was incorporated in 1981 as an Infosys Consultants Private limited. In 1992, the company was converted into a public limited company. In the year 1995-96, it became the first software company to value its human resources in India. Lev and Schwartz model has been used for the purpose of valuation of human resources of the organization. It considers all direct and indirect benefits earned both in India and abroad for the valuation purpose. The incremental earnings based on age and group are taken into consideration. Balance sheet with intangibles is also disclosed by the company in its reports.

Human Resource Accounting System of Rolta India: It is a multinational software development and services company, established in 1989. The economic approach model i.e. Lev \& Schwartz model is the basis of calculation of human resources of the company. The company considers all direct and indirect benefits earned by employees as a basis for calculation. Average increment is based on the increment paid during last three years. Retirement age is taken as per company's policy. Based on these assumptions human resource value was calculated considering different discount rates for different years to arrive at the present value of future earnings.

Comparative Study of HRA System of Selected Companies: In Table 1, an attempt has been made to show the various aspects considered for valuation by these companies for 2010-11

From the table it is clear that all the organizations are using Lev and Schwartz model for valuation except Cement Corporation of India Limited. CCI used the Lev\& Schwartz, Flamholtz, Jaggi\& Lau model with appropriate modifications as suitable for the organization to overcome the limitations of Lev \& Schwartz model. In India, the organizations used Lev and Schwartz model for valuation of human resources though this model has its own limitations. Discount rate used by the companies to value human resources is to be considered for the purpose of comparison of status of human resources of different organizations. CCI did not disclose the discount rate as well as criteria for discount rate. All the companies disclosed the determinants of earnings except CCI. In Table 2, human resource value and number of employees of different, all selected companies are disclosed for the period of five years. 
Table1: Various aspects considered for valuation

\begin{tabular}{|c|c|c|c|c|}
\hline Organization & CCI & HPCL & Infosys & Rolta \\
\hline $\begin{array}{ll}\text { Year } & \text { of } \\
\text { introducing } & \\
\text { HRA } & \end{array}$ & $1979-80$ & 1981-82 & $1995-96$ & 2002 \\
\hline $\begin{array}{l}\text { Title used for } \\
\text { HRA } \\
\text { information }\end{array}$ & $\begin{array}{l}\text { "Our Employees- Our } \\
\text { Greatest Assets" }\end{array}$ & $\begin{array}{l}\text { Human Resource } \\
\text { Accounting }\end{array}$ & $\begin{array}{l}\text { Human Resource } \\
\text { Valuation }\end{array}$ & $\begin{array}{l}\text { Human Resource } \\
\text { Valuation }\end{array}$ \\
\hline $\begin{array}{l}\text { Model used for } \\
\text { valuation }\end{array}$ & $\begin{array}{l}\text { Lev \& Schwartz (1971), } \\
\text { Flamholtz (1974) and } \\
\text { Jaggi\& Lau (1974) with } \\
\text { appropriate modifications }\end{array}$ & $\begin{array}{l}\text { Lev and } \\
\text { Schwartz (1971) }\end{array}$ & $\begin{array}{l}\text { Lev } \\
\text { Schwartz } \\
\text { (1971) }\end{array}$ & $\begin{array}{l}\text { Lev and Schwartz } \\
\text { (1971) }\end{array}$ \\
\hline $\begin{array}{l}\text { Discount rate } \\
\text { per annum }\end{array}$ & Not Reported & $8.25 \%$ & $11.21 \%$ & $9.68 \%$ \\
\hline $\begin{array}{l}\text { Criteria for } \\
\text { discount rate }\end{array}$ & Not Reported & Not Reported & Cost of capital & $\begin{array}{l}\text { Weight average } \\
\text { cost of capital }\end{array}$ \\
\hline Average age & 53 years & 46years & 27 years & Not Reported \\
\hline $\begin{array}{l}\text { Determinants } \\
\text { of earnings }\end{array}$ & Not Reported & $\begin{array}{l}\text { Direct \& indirect } \\
\text { benefits as cost } \\
\text { to company basis }\end{array}$ & $\begin{array}{l}\text { Direct \& indirect } \\
\text { benefits earned } \\
\text { in India \& abroad }\end{array}$ & $\begin{array}{l}\text { Direct \& indirect } \\
\text { benefits earned in } \\
\text { India \& abroad }\end{array}$ \\
\hline
\end{tabular}

Source: Annual reports of companies

Table 2: Employees and value of human resources of selected companies for 2006-07 to 2010-11

\begin{tabular}{|c|c|c|c|c|c|c|c|c|c|c|}
\hline Year & 2006-07 & & 2007-08 & & 2008-09 & & 2009-10 & & 2010-11 & \\
\hline 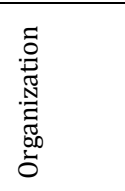 & $\begin{array}{l}\text { No. of } \\
\text { employees }\end{array}$ & $\begin{array}{l}\text { HR } \\
\text { Value } \\
\text { (Rs in } \\
\text { crores) }\end{array}$ & $\begin{array}{l}\text { No of } \\
\text { employees }\end{array}$ & $\begin{array}{l}\text { HR } \\
\text { Value } \\
\text { (Rs in } \\
\text { crores) }\end{array}$ & $\begin{array}{l}\text { No. of } \\
\text { employees }\end{array}$ & $\begin{array}{l}\text { HR } \\
\text { Value } \\
\text { (Rs in } \\
\text { crores) }\end{array}$ & $\begin{array}{l}\text { No. of } \\
\text { employees }\end{array}$ & $\begin{array}{l}\text { HR } \\
\text { Value } \\
\text { (Rs in } \\
\text { crores) }\end{array}$ & $\begin{array}{l}\text { No. of } \\
\text { employees }\end{array}$ & $\begin{array}{l}\text { HR } \\
\text { Value } \\
\text { (Rs in } \\
\text { crores) }\end{array}$ \\
\hline $\mathrm{CCI}$ & 1523 & 115.37 & 1460 & 160.31 & 1159 & 202.85 & 1078 & 237.53 & 988 & 256.41 \\
\hline HPCL & $\begin{array}{l}\text { Not } \\
\text { Reported }\end{array}$ & $\begin{array}{l}\text { Not } \\
\text { report } \\
\text { ed }\end{array}$ & 10949 & 12730 & 11246 & 13147 & 11291 & 15654 & 11248 & 18493 \\
\hline INFOSYS & 72241 & 57452 & 91187 & 98821 & 104850 & 102133 & 113796 & 113287 & 130820 & 135105 \\
\hline ROLTA & 3530 & 6282 & 4700 & 10671 & 4620 & 13644 & 4520 & 15321 & 3885 & 17092 \\
\hline
\end{tabular}

Source: Annual Reports of companies for 2006-07 to 2010-11.

The above table clearly indicates the strength of employees of the CCI, HPCL, Infosys and Rolta. The values of the human resources also disclosed in the table for different years. The value of human resources is increasing whereas number of employees is decreasing every year from 2006-07 onwards in case of CCI. The value of employees is increasing due to increase in benefits provided to employees. HPCL annual report for the year did not disclose the value of human resources i.e. why the column for that year is left blank. The value of human resources increased partly due to increase in salary and partly due to increase in number of employees. The value of human resources increased 2.22 times, 1.45 times, 2.35 times and 2.72 times for CCI, HPCL, Infosys and Rolta respectively during the period of study i.e. 2006-07 to 2010-11 (a period of five years). The human resource accounting information in the annual reports of these organizations form only a part of the supplementary information. It lacks authenticity, as it is unaudited. Moreover, not all organizations disclose all the variables that have been considered for valuation of human resources. None of the organizations reporting human resource accounting information was providing HRA information as a part of the income statement and for the balance sheet. Only CCI and Infosys disclosed human resource value in 'Social Balance Sheet'. The value of human resource shown on the asset side under the head 'human asset' and 
the same amount was shown under the head 'contribution towards human resources' on the liability side of Balance Sheet. It means that their net value is zero. However, all these organizations have valued their human resources but it has not been mentioned as to how they are treating the huge expenditure incurred by them on hiring, training and developing their employees. Obviously, they are charging such expenditure wholly to the profit and loss, which is against the accounting principles.

Ranking of the Selected Companies: An Index of human resource accounting information disclosure is prepared and the scores were assigned based on various variables disclosed by these different organizations in their annual reports. The Index include those items that are considered important from the point of view of the users of the HRA information and certain variables were identified after scanning the annual reports for the period 2007-08 to 2010-11 i.e. five years. The non-availability of these items (in the annual reports) may render the comparative analysis very difficult. The following fifteen variables were included in the Index. In Table 3, scores were assigned to these organizations based on information disclosed for five years. One score is given for one-year information and total five scores for one variable for a company. As mean scores of Infosys is maximum i.e. 15. It reports all the variables therefore; it has been ranked on first position. Least information is disclosed by Rolta India therefore it stands on fourth rank. HPCL got second and CCI third rank. All the selected companies report one variable i.e. method used for the purpose of valuation. The scores of different variables show the maximum importance gained by any variable by all the selected companies.

Table 3: Scores of the selected companies based on information disclosed

\begin{tabular}{lllllll}
\hline S/N & Organization Variables & CCI & HPCL & Infosys & Rolta & Total \\
\hline 1 & No of employees & 5 & 5 & 5 & 0 & 15 \\
2 & Category of employees & 5 & 5 & 5 & 0 & 15 \\
3 & Age wise distribution & 5 & 4 & 5 & 0 & 14 \\
4 & Average age of employees & 5 & 4 & 5 & 0 & 14 \\
5 & Model used for valuation & 5 & 4 & 5 & 5 & 19 \\
6 & Discount rate & 0 & 4 & 5 & 5 & 14 \\
7 & Criteria for discount rate & 0 & 4 & 5 & 5 & 14 \\
8 & Determinants of earnings & 0 & 4 & 5 & 5 & 14 \\
9 & Category wise disclosure of HR value & 5 & 4 & 5 & 0 & 14 \\
10 & Value added & 5 & 5 & 5 & 0 & 15 \\
11 & Profits/human resources & 0 & 4 & 5 & 0 & 09 \\
12 & Value added/ human resources & 0 & 0 & 5 & 0 & 05 \\
13 & HR's/total resources & 0 & 4 & 5 & 0 & 09 \\
14 & Employee cost/HR'S & 0 & 4 & 5 & 0 & 09 \\
15 & Balance sheet with HR's & 5 & 0 & 5 & 0 & 10 \\
16 & Total scores & 40 & 55 & 75 & 20 & N=190 \\
17 & Mean Scores & 8 & 11 & 15 & 4 & \\
18 & Ranks & 3 & 2 & 1 & 4 & \\
\hline
\end{tabular}

Source: Annual reports of companies for the year 2006-08 to 2010-11

For the purpose of ranking of the organizations mean scores are calculated. The following formula was applied to calculate mean scores.

Mean Scores $=$ Total Scores $/$ Total no. of years i.e. 5

\section{Conclusion and Recommendations}

Summary and Suggestions: The study of the HRA system of the four organizations reveals that most of these organizations applied the Lev \& Schwartz model for valuation of their human resources. This model calculates the present value of human resources in terms of the present value of future earnings of human resources. Whereas Cement Corporation of India mentioned in their annual reports that, they were considered the refinements suggested by Eric Flamholtz and Jaggi \& Lau in the valuation of human resources of their organizations. All the modifications suggested by Flamholtz and Jaggi were not incorporated by the CCI as it does not considered the possibility of leaving the organization by an individual before the retirement. Many organizations that tend to introduce the HRA are finding it difficult to arrive at a generally 
agreeable method of valuation and reporting for human resources. Any valuation method is based on certain assumptions, which may or may not come to be true. There is no universally accepted model for valuation of human resources. Experts developed a number of models during last few decades but none got credit of convenience and objectivity. Any valuation method is based on certain assumptions that may or may not come to be true and when we try to make a comparative study of human resources of two organizations, we face problem because different organizations used different approaches for valuation of human resources. Therefore, there is a need to develop a model that is acceptable to all the companies. The value assigned by Indian companies to their human resources first denotes the present value of the costs with respect to remaining service life of an employee that an organization would bear rather than the contributions that it will receive from human resources. It appears that the organizations have stressed more upon the 'Human Capital Accounting' rather than the 'Human Asset Accounting'. Therefore, there is a need to develop asset approach as regards to human resources. Based on the results of the information disclosed by the selected companies it can be inferred that Rolta India limited provides minimum information regarding the different variables related to human resources. Therefore, it should provide more information in its annual reports.

Recommendations: Human Resource Accounting has a great potential in the modern age of professionalization particularly in the case of labor-intensive service industry where human resource constitutes prime resource. HRA information thus would be of immense help in decision making both for internal and external users. Therefore, organizations should adopt HRA system. The conceptual thinking about valuation of human resources is still in a developing stage. No model of HRA is accepted by the accounting bodies all over the world. The models devised so far for valuation of HRA have been developed in the USA taking into consideration the prevailing environment. Most of the companies are using the Lev and Schwartz model with or without modifications as per their convenience. Considering the significance of human resources in knowledge based sectors initiatives should be taken by the government along with other professionals, researchers and accounting bodies both at the national and international levels for the measurement and reporting of such valuable assets. Researchers should come forward to review the models as per the requirements of our country.

Limitations of the study: The said study is based on secondary data. Information disclosed by the various companies in their annual reports is used for the purpose of study. The limitation is that secondary data influence the study. Only four companies are considered for the purpose of study of human resource accounting.

\section{References}

AAA Committee. (1973). Report of the AAA Committee on Accounting for Human Resources. The Accounting Review, Supplement to, 48, 189.

Batra, G. S. \& Bhatia, B. S. (1994). Human Resource Valuation: A Study of Indian Corporate Sector. Journal of Accounting and Finance, 8(1), 43-57.

Bhatia, B. S. \& Singh, G. (1992). Human Resource Accounting in India. Journal of Accounting and Finance, 6(2), 217-225.

Brummet, R. L, Flamholtz, E. G. \& William C. P. (1968). Human Resource Management: A Challenge for Accountant. The Accounting Review, 43(2), 217-224.

Chakraborty, S. K. (1976). Human Asset Accounting: The Indian Context in Topics in Accounting and Finance. Oxford University Press.

Dasgupta, N. D. (1978). Human Resource Accounting. Sultan Chand and Sons, New Delhi.

Elias, N. (1972). The Effects of Human Asset Statement on Investment Decision: An Empirical Research in Accounting. Journal of Accounting Research (Supplement Empirical Research in Accounting Selected Studies), 10, 215-233.

Gambling, T. E. (1974). A System Dynamic Approach to Human Resource Accounting. The Accounting Review, 49(3), 538-546.

Giles, W. J. \& Robinson, D. F. (1972). Human Asset Accountants. Institute of Personnel Management and Institute of Cost and Management Accountants, London.

Gul, F. A. (1984). An Empirical Study of the Usefulness of Human Resources Turnover Cost in Australian Accounting Firms. Accounting Organization and Society, 9, 233-239. 
Gupta, D. K. (1990). The Lev and Schwartz Model Based Human Resource Accounting in India: Some Issues. Indian Journal of Accounting, 20(1), 79-81.

Hekimian, J. S. \& Jones, C. H. (1967). Put People on Your Balance Sheet. Harvard Business Review, JanuaryFebruary 45, 107-108.

Hermanson, R. H. (1964). Accounting for Human Assets. Occasional Paper No. 14, Graduate School of Business Administration, Michigan State University, 1-69.

Jaggi, B. \& Lau, H. S. (1974). Towards a Model for Human Resource Valuation. The Accounting Review, 49(2), 321.

Flamholtz, E. G. (1971). A Model for Human Resource Valuation: A Stochastic Process with Services Rewards,

Accounting Review, 46(2), 253-267.

Flamholtz, E. G. (1972). Towards a Theory of Human Resource Value in Formal Organizations. The Accounting Review, 48(4), 666-678.

Flamholtz, E. G. \& Likert, E. (1973). HRA: Measuring positional replacement costs. Human Resource Management 12(Spring), 8-16.

Flamholtz, E. G. (1976). The Impact of Human Resource Valuation on Management Decision: A Laboratory Experiment. Accounting, Organization and Society, 1, 153-65.

Likert, R. (1967). The Human Organization: In Management and Value. McGraw Hill Book Co, New York, 8384.

Lev, B. \& Schwartz, A. (1971). On the use of the Economic Concept of Human Capital in Financial Statements. Accounting Review, 46(1), 103-112.

Myer's, S. M. \& Flowers, V. S. (1974). A Framework for Measuring Assets. California Management Review, 16 (4).

Morse, W. J. (1973). A Note on the Relationship between Human Asset and Capital. The Accounting Review, 37 (3), 589-593.

Ogan, P. A. (1976). Human Resource Value Model for Professional Service Organizations. The Accounting Review, 51(2), 306.

Prakash, O. (1997). Human Resource Accounting Practices in Bharat Heavy Electricals Limited. Finance India, 11(1), 92-94.

Patra, R. \& Khatik, S. K. (2003). HRA Policies and Practices: A Case Study of BHEL Limited, Bhopal, India. International Journal of HRD and Management, 3(4), 285-296.

Paton, W. A. (1962). Accounting Theory. Chicago American Studies Press, 448-487.

Rao, D. P. (1993). Human Asset Accounting: An Evaluation of the Indian Practices. ASCI Journal of Management, 22. 37- 42.

Sonara, C. K. \& Patel, A. (2009). Valuation and Reporting Practices of Human Resource Accounting in India. The Management Accountant, 44, 16-19.

Schwan, E. S. (1976). The Effects of Human Resource Accounting Data on Financial Decisions: An Empirical Test. Accounting, Organization and Society, 1(2), 219-237.

Tomassini, L. A. (1977). Assessing the Impact of Human Resource Accounting: An Experimental Study of Managerial Decision Preferences. The Accounting Review, 52(4), 904-914.

Verma, S. B. (1999). HRA Practices in Public Sector Undertakings in India. The Management Accountant, 34(8), 575-582. 